\title{
How to cultivate the innovative ability of students relying on electrical engineering training center
}

\author{
Yang Xiaojing, Yin Zhongdong, Wu Zhiming, Li Guangsen \\ School of Electric and Electronic Engineering, North China Electric Power University, Beijing, China
}

\begin{abstract}
Practice teaching is not only an important part of teaching work in university, but also an important way for cultivating students' innovative thinking and ability. Aiming at optimizing the practice teaching system, deepening the university-industry cooperation, implementation of open teaching and close combination of scientific research and teaching, this paper explains how to fostering applied innovative talents relying on electrical engineering training center in our university.

Index Terms - practice teaching, innovative ability, engineering training center.
\end{abstract}

As the important part of higher education, the practice teaching which bear the main work of knowledge innovation ,education and teaching reform, plays an irreplaceable role in cultivating comprehensive quality of the students, especially in fostering innovative talents. But from the current situation, there are many problems in the practice teaching of various colleges such as insufficient attention, lack of scientific teaching system, having teaching content lagging the development of engineering technology, and insufficient incentive mechanism for the teachers and students, etc. The above problems result in the situation that the students can not use knowledge flexibly and lack the skills of in-depth analysis and solving related problem. As the only university directly under the ministry of education having the subject characteristic of electric power, our university set up electric engineering training center(hereinafter referred to as the center) in November 2006 under the support of the special funds of the ministry of education for repairing and purchasing. The center carries out the engineering foundation, comprehensive practice and innovative quality education for the entire school undergraduates . Therefore, how to implement and promote the practice teaching and cultivate new-type talents with innovation spirit and practice ability relying on the centre has become an important research topic for teaching workers in our university.

\section{Optimization of the practice teaching content and system}

The heart of the practice teaching system establishment is to optimize curriculum structure. In order to lead the students from the secondary discipline which has narrow range of knowledge to a higher level and make them grasp the essential relations between foundation courses and professional courses in the specialty of electrical engineering and automation, the center builds a multi-level and modular curriculum system. Every practice course consists of several training modules including industrial cognition, disassembling practice, system design and building, integrated innovation, simulation training, running ,testing, production and promotion. Owing to different levels of technology and methods within the appropriate module and flexible structure according to different discipline requirements, the practice teaching courses present three levels, respectively are the basic, comprehensive and innovative level. Basic training level carry out cognitive engineering training and basic training in electrical engineering technology for junior students, aiming at cultivate interest, teach engineering knowledge, inspire the engineering consciousness and strengthen mode of electrical engineering disciplines and modern industrial production .Comprehensive training level of the teaching content has the characteristics of interdisciplinarity and comprehensiveness, which emphasizes digest, penetration and the integrated use of knowledge. By experience system design, the production of hardware, writing software, debugging, measurement and writing reports, the students learn how to analysis and solve the problems by applying electrical engineering related knowledge and operation skills. Innovation training level mainly face the students who are keen on scientific exploration and technological development. By form of graduation design, course contests, extracurricular activities of science and technology and participation in teachers' scientific research subject, the students can come into contact with more deep going and generalized subjects compared to the first two levels. Innovation is not invention or do something unconventional or unorthodox, but is to let the students have more opportunities of independent thinking, creative use of knowledge and personality development .With particular emphasis on the students' scientific research consciousness and research method instruction, this level guides the student to think independently, pursue truth, respect science, bold innovation, so that the practical ability and innovation consciousness can be improved greatly. The above three layers are formed from low to high, from accepting knowledge to cultivating ability of practical teaching system, which can not only guarantee the basic training and the cultivation of basic skills, but also satisfies the requirement of high level ability training. The whole teaching is integrated into the university four years of teaching process plan step by step, which is arranged from shallow to deep, from easy to difficult, from components to the system. It cultivate practice ability and innovation consciousness gradually, hierarchically and comprehensively.

\section{2 . Constructing an open practice teaching environment}

The center allows students to choose their practice 
content, which is not limited by time schedule. At the same time, we require the students check material, design the scheme, choose equipment and finishing the production and debugging independently. The practice teaching content can come from many aspects: bsides regular innovative integrated design and research topic within the teaching plan of the center, we also encourage teachers to have their scientific research project open to students who hold the post of scientific assistant. In this process, the centre provides hardware support and technical support. In addition, according to teaching purpose and training object's maturity, the center adopts different forms of open practice teaching. For basic items, we carry out limited open type; for integrated items, we make an appointment open type because the students have mastered the basic knowledge and preliminary practice ability; for innovative items, we adopt complete open type. Hierarchical open teaching system not only make the students become the main body and causes them to make full use of teaching resources, but also extend the teaching content in time and space and promote hardware and software resource sharing."Open" is not equal to let themselves go. In order to ensure the quality of open practice teaching, we require the teacher to strengthen the guidance of students so as to avoid open teaching becoming a mere formality. For this purpose, the center continuously improve the quality of the guidance personnel and acknowledge their workload for open practice guidance. In addition, the center developed an intelligent management system of open practice teaching based on campus network by utilizing advanced information technology, which provide good cognitive learning environment for learners, including abundant learning resources, rapid information retrieval and convenient communication tool.

\section{Broadening the practice teaching relying on university- industry cooperation way}

The center pays much attention that the teaching face scientific research and the society. On the one hand, we encourage teachers to integrate results of their scientific and technological projects into practice teaching in order to promote the transformation of scientific ideas to the teaching and the development of practice teaching to higher level. On the other hand, we make full use of social resources by establishing good cooperation relations With scientific research units, high-tech companies, state-owned large and medium-sized enterprises in order that the practice teaching keep up with the development of engineering technology. As a part of teaching resource, the social resources not only promote the improvement of teaching conditions and expand the connotation of hardware resources, but also avail in improving the academic level of practice teaching team and developing more comprehensive and innovative practice project .It has been proved that the education mode in which teaching is the main body improved by scientific research and social services is beneficial to enhance the overall level of practice teaching. It is the only way for the development of higher engineering education.

\section{Emphasizing the combination of scientific research and teaching}

Whether we can cultivate innovative talents that suit the development of society, to a large extent depends on whether teaching is promoted by scientific research. North China Electric Power University is a research type university, in which we create an academic

tmosphere for the teaching of scientific research so that we can introduce new scientific and technological achievements into teaching. As a part of practical innovation system, the students' scientific research training plan, students' scientific research project, the engineering college students innovation training and competition of science and technology allow students to participate fully in the whole process of scientific research, so that we have initially formed a new mechanism to cultivate students innovation consciousness which has been proved quite effectively. By making the undergraduate students to participate in scientific research, teaching and scientific research turn into a whole, meanwhile teachers' "teaching" totally integrate into the process of research. Similarly, students' learning is also integrated into the research. Through direct participating in the teacher's research, students get opportunities to learn basic methods of scientific research and explore frontier problems under the guidance of tutor step by step .so that scientific research ability and innovation ability, will be improved.

\section{Conclusion}

In the system of training innovative talents, practice teaching is an important link. How to break through the traditional teaching mode, carry out the innovative practice teaching, and make it more intuitive, practical and innovative, is a topic. worth exploring .In addition to the above mentioned, there are many aspects which need us to explore and improve. Our goal is to build up a mechanism conducive to cultivating innovative talents, to explore a suitable way for a variety of technical skill training and to develop more talents for the economic construction .

\section{References}

[1] DU Jun, etc. In order to develop comprehensive ability, establish open electrical lab teaching platform., Journal of Electrical \& Electronic Engineering Education ,2008 (S1) : 128-134 ·

[2] Wang Jingming, Zhu Meiying, Lu Zhihong. Strengthening construction of experimental teaching demonstration center and cultivating innovative talents. Experimental Technology and Management, 2012, 29 (3) : $120-122$.

[3] DuYubo. Comprehensively promote quality education to cultivate highquality innovative talents. China Higher Education Research,2012(1).

[4] ZHANG Zhi-hua, LI Hao-guang. The practical process of the electrical engineering major based on the combining of production studying research. Journal of Electrical \& Electronic Engineering Education, $2012,34(1): 52-54$.

[5] HU Jian.Research on the cultivating patterns for innovative talents based on research concept. Journal of Heilongjiang College of Education, 2012, $31(1): 19-21$. 